Claremont Colleges

Scholarship@ Claremont

WM Keck Science Faculty Papers

W.M. Keck Science Department

$1-1-1989$

\title{
Patterns of Species Co-occurrence in the Antillean Bat Fauna
}

Donald A. McFarlane

Claremont McKenna College; Pitzer College; Scripps College

\section{Recommended Citation}

McFarlane, D.A. (1989). "Patterns of species co-occurrence in the Antillean bat fauna." Mammalia 53: 59-66.

This Article is brought to you for free and open access by the W.M. Keck Science Department at Scholarship @ Claremont. It has been accepted for inclusion in WM Keck Science Faculty Papers by an authorized administrator of Scholarship @ Claremont. For more information, please contact scholarship@cuc.claremont.edu. 


\title{
Patterns of Species Co-occurrence in the Antillean Bat Fauna
}

\author{
by D.A. MCFARLANE
} Section of Birds and Mammals, Natural History Museum of Los Angeles County,
900 Exposition Boulevard, Los Angeles CA 90007, U.S.A.

Summary. - The bat fauna of 25 Antillean islands is presented as a species presenceabsence matrix, and used to construct a large population of randomized null-model matrices by Monte-Carlo simulation techniques. Comparison of the observed data matrix with the randomized population reveals a statistically significant departure from randomness which is interpreted as evidence of community structure. The Antillean bat fauna is marked by a pattern of high species co-occurrence, with endemics dominating in the northern Antilles and undifferentiated South American taxa dominating in the southern Antilles. The 'checkerboard' distributions which have been identified in the bird populations of some tropical archipelagoes are absent in Antillean bat fauna.

Résumé. - Les espèces de chauves-souris de 25 îles des Antilles sont, d'une part, récapitulées dans une matrice en présence-absence et, d'autre part, utilisées pour construire, au hasard, une longue série de matrices de distribution aléatoire. La comparaison de ces deux types de matrices montre que les données observées diffèrent de manière statistiquement significative d'une répartition au hasard, ce qui est interprété comme une preuve de la structuration du peuplement.

La faune des chauves-souris des Antilles est marquée par un fort degré de coexistence des espèces, avec une dominance des endémiques dans les Antilles du nord et des taxons sud-américains indifférenciés dans les Antilles du sud. Les répartitions en damier qui ont été mises en évidence dans les populations d'oiseaux de quelques archipels tropicaux font défaut chez les chauves-souris des Antilles.

\section{INTRODUCTION}

The analysis of matrices of presence-absence data, based on lists of species from various islands, has usually been undertaken in one of two ways. In the first approach, plots of column totals (island species-richnesses) against island area and other physiographic parameters have been analysed statistically with linear and multiple regression models to investigate what has been called the species-richness/island area relationship (MacArthur and Wilson 1967 ; Connor and McCoy 1979). An earlier analysis of West Indian bats in a similar vein was undertaken by Koopman (1958), but without statistical treatment. Recently,

Mammalia, t. 53, $n^{\circ}$ 1, 1989. 
Lazell and Jarecki (1985) have attempted to identify " supersaturated " bat faunas on some very small islands within the British Virgin Islands.

The second approach to the analysis of presence-absence matrices involves the search for non-random patterns of positive and negative species associations (Simberloff 1978 ; Wright and Biehl 1982 ; Gilpin and Diamond 1982). The Gilpin and Diamond log-linear model was developed to overcome a problem inherent in earlier analyses by Connor and Simberloff (1979). In the Connor-Simberloff procedure, presence-absence matrices were shuffled and re-shuffled in multiple Monte-Carlo simulations to obtain 'randomized' matrices. The original data matrix was then compared to the population of computer-generated 'randomized' matrices and tested for statistically significant differences. Unfortunately, the Connor and Simberloff procedure, which reshuffles the matrix by locating and swapping elementary $2 \times 2$ submatrices, does not erase the checkerboard patterns of two or more species with mutually exclusive but geographically irregular distributions. Such patterns are characteristic of deterministic processes. If the 'null' model preserves the original checkerboard pattern then it will always be concordant with that pattern. Thus the Connor and Simberloff procedure is biased towards so-called Type II statistical errors.

Gilpin and Diamond $(1982,1984)$ solved this problem by developing a procedure based on incidence probabilities. Their technique is a powerful tool for illustrating community-wide trends of species co-occurrence.

I have used the Gilpin-Diamond technique to test the hypothesis that the co-occurrence of bat species in the Antilles is not random, but is structured by ecological 'assembly rules'. The data matrix consists of species lists for bats occuring on 25 Antillean islands.

\section{METHODS}

The probability that a given species will occur on a given island, its 'incidence probability', is defined by Gilpin and Diamond (1982) as

$$
P_{i j}=R_{i} C_{j} / T
$$

where $P_{i j}$ is the probability that species $i$ will occur on island $j, R_{i}$ is the number of islands occupied by species $i, C_{j}$ is the observed number of species on island $j$, and $T$ is the observed total instances of species occurrences on the islands under study. Observed and expected numbers of shared islands for each possible pairwise species combination can be compared, and the standard deviate determined by the equation

$$
D_{i k}=O_{i k}-E_{i k} / S D_{i k}
$$

where $O_{i k}$ is the observed number of islands shared by species $i$ and $k, E_{i k}$ is the expected number of islands shared by species $\mathrm{i}$ and $\mathrm{k}$ from the equation

$$
E_{i k}=P_{i j} . P_{k j}
$$

and $\mathrm{SD}_{\mathrm{ik}}$ is the standard deviation of this estimate from the equation

$$
S_{i k}=P_{i j} \cdot P_{k j}\left(1-P_{i k} \cdot P_{k j}\right)
$$

The null model in this procedure is a normal distribution of standard deviates (mean $=\mathrm{O}$, standard deviation $=1$ ) against which the observed distribution of standard deviates can be compared graphically and tested for non-conformity using the chi-squared statistic. 
The basic equations of Diamond and Gilpin (1982) were incorporated into a microcomputer program written in GWBASIC (McFarlane 1987), and used to analyse a data set consisting of 53 species on 25 islands (Appendix 1).

The phytophagous bats (24 species on 25 islands), and the non-phytophagous bats (29 species on 25 islands) were analysed as two seperate subsets.

\section{RESULTS AND DISCUSSION}

The distributions of the observed and null model data from the analysis of the data set and its two subsets are shown in Fig. 1, from which it is appears that the observed distribution of standard deviates departs markedly from the

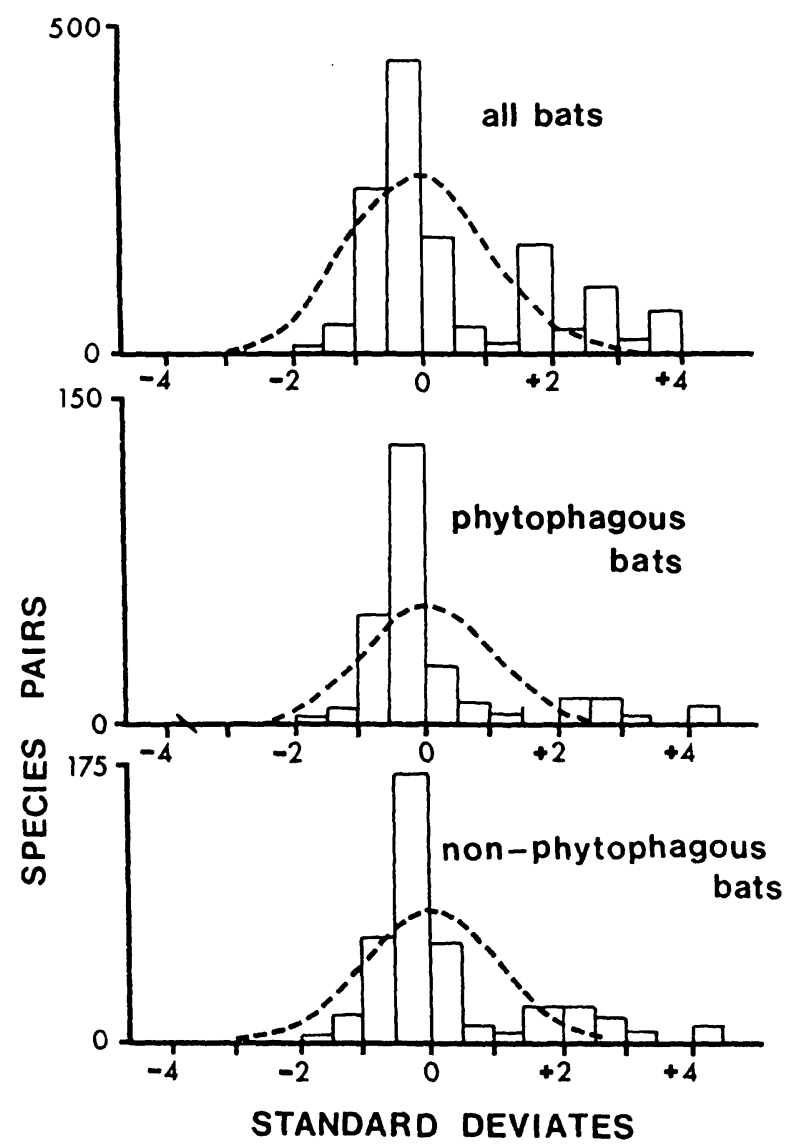

Fig. 1. - Observed (histogram) and null-model (curve) distributions of pairwise associations for Antillean bat species. Abscissa ; difference between the observed and expected number of islands shared by a species pair. Ordinate ; number of species pairs exhibiting such a difference. 
null model in all three cases. Summary statistics (Table 1) show that the probabilities of drawing the observed distributions from the null model population are extremely small - in each case very much less than $P=10^{-6}$. Table 2 provides examples of the 1378 possible pairwise combinations, selected to illustrate the range of biogeographic relationships.

TABLE 1. - Summary Statistics, Gilpin-Diamond Co-occurrence Analysis.

\begin{tabular}{lcccc} 
& \# of Dik's & Chi-Squared & df & Probability \\
\hline All extant & 1378 & 17015 & 19 & $<<10^{-6}$ bats \\
Phytophagous & 276 & 6168 & 19 & $<<10^{-6}$ species \\
Non-phytophagous & 406 & 7709 & 19 & $<<10^{-6}$ species \\
\hline
\end{tabular}

Dik is the standard deviate of the difference between the observed and expected values according to the equation

$$
D_{i k}=O_{i k}-E_{i k} / S D_{i k}
$$

where $\mathrm{O}_{i k}$ is the observed number of islands shared by species $i$ and $k, E_{i k}$ is the expected number of islands shared by these species, and $S_{i k}$ is the standard deviation of this estimate.

The probability values represent the likelehood of drawing the observed distributions from the null model distributions. Degrees of freedom (df) are also shown.

The data set and its two subsets show similar patterns; a distribution with an elongate positive tail, shortened negative tail, and an excess of species pairs in the range of 0 to -0.5 . This pattern corresponds to circumstances in which some species pairs occur very much more often than expected, whilst many more

TABLE 2. - Representative Taxa and Log-Linear Model Statistics.

\begin{tabular}{|c|c|c|c|c|}
\hline & $\mathrm{O}_{\mathrm{ik}}$ & $E_{i k}$ & $S D_{i k}$ & $\mathrm{D}_{\mathrm{ik}}$ \\
\hline $\begin{array}{l}\text { Artibeus jamaicensis/ } \\
\text { Brachyphylla cavernarum. }\end{array}$ & 18 & 14.44 & 1.74 & 2.04 \\
\hline $\begin{array}{l}\text { Carollia perspicillata/ } \\
\text { Anoura geoffroyi. }\end{array}$ & 1 & 0.05 & 0.22 & 4.24 \\
\hline $\begin{array}{l}\text { Glossophaga longirostris/ } \\
\text { Artibeus lituratus. }\end{array}$ & 2 & 0.30 & 0.54 & 3.12 \\
\hline $\begin{array}{l}\text { Phyllops haitensis/ } \\
\text { Phyllops falcatus. }\end{array}$ & 0 & 0.05 & 0.22 & 0.22 \\
\hline $\begin{array}{l}\text { Carollia perspicillata/ } \\
\text { Stenoderma rufum. }\end{array}$ & 0 & 0.15 & 0.38 & 0.39 \\
\hline $\begin{array}{l}\text { Artibeus lituratus/ } \\
\text { Phyllonycteris aphylla. }\end{array}$ & 0 & 0.10 & 0.31 & 0.31 \\
\hline
\end{tabular}

For explanation of statistics, see text. Examples represent the following categories of biogeographic relationships : 1) Two widespread taxa. 2 and 3) Two undifferentiated South American invaders. 4) Two Greater Antillean endemics. 5 and 6) An undifferentiated South American invader with an Antillean endemic.

pairs occur slightly less often than expected. The majority of the taxa producing small negative distributions are closely related Greater Antillean endemics that show checkerboard patterns but have very restricted distributions. The endemic 
Stenodermines Ariteus, Stenoderma and Phyllops are examples. Small negative deviations are also produced by pairwise combinations of some Antillean endemics with undifferentiated South American forms occurring on one or two of the southern Lesser Antillean islands, for example Sternoderma and Carollia.

High positive deviations are for the most part the result of the co-occurrence of taxa with only a single island distribution, but of more divergent taxonomic and ecological relationships - for example Ariteus flavescens and Phyllonycteris aphylla on Jamaica, or Anoura geoffroyi and Carollia perspicillata on Grenada. These high positive deviations reflect similarities in the origin or history of the species - high endemism on Jamaica, and recent immigration to Grenada.

In the data set and its two subsets, the absence of large negative deviations from the mean is marked. Large negative deviations would be expected to be produced by pairs of taxa which are both wide ranging and distributed in nearperfect checkerboard patterns. In contrast to the bird species of the Bismarck Archipelago (Gilpin and Diamond 1984), such taxa are conspicuously absent from the Antillean chiropterofauna. In the Caribbean region, checkerboard distributions are largely restricted to single island endemics. Wide ranging taxa such as Artibeus jamaicensis and Brachyphylla cavernarum exhibit high positive cooccurrence (Table 2).

Three conclusions can be drawn from this study :

1) The pattern of bat species co-occurrence in the Antilles is non-random, with many species pairs co-occurring much more often than is predicted by the null model.

2) Widely ranging species with checkerboard distributions are absent from the Antillean bat fauna.

3) The structure of bat assemblages on the Greater Antillean islands is dominated by the co-occurrence of single-island endemics, wheras a similar structure in the Lesser Antilles is dominated by the co-occurrence of undifferentiated South American taxa.

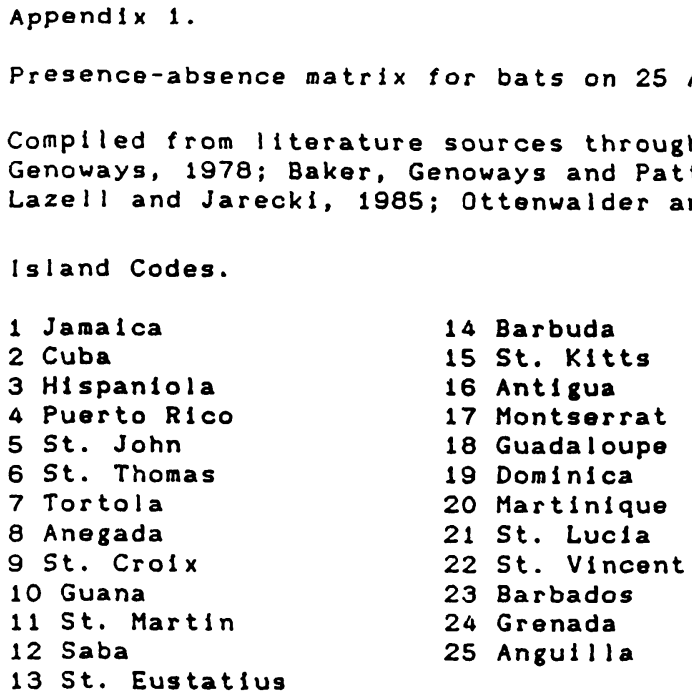


Species Codes.

Glossophaga longlrostris Glossophaga sorcina

3 Monophyllus plethedon

Monophyllus redmanl

Anoura seoftroyl

Carollia persplcallata

Sturnira ludoulci

Sturnira thomas 1

Chiroderma improvisum

10 Artibeus cinereus

11 Artibeus lamalcens is

12 Artibeus 11 turatus

13 Ardops nichollst

14 Phyllops falcatus

15 Phyllops hattensis

16 Arlteus 1 lavescens

17 Stenoderma rufum

18 Brachyphyl la cavernarum

19 Brachyphylla nana

20 Erophyl la bomblitrons

21 Erophylla sezekornl

22 Phyllonycter is obtusa

23 Phyllonycter is poeyl

24 Phyllonycter is aphylla

25 Peropteryx macrotis

26 Noctillo leporinus

27 Pteronotus parnel1 1

28 Pteronotus tullglnosus
29 Pteronotus macleay 1

30 Pteronotus davy 1

31 Mormoops blalnull II

32 M1cronycteris megalotis

33 Macrotus waterhous 11

34 Natalus stramineus

35 Natalus micropus

36 Myotis dominicensis

37 Myotis martinlquensis

38 Myotis nigrlcans

39 Epteslcus fuscus

40 Epteslcus guadaloupens is

41 Epteslcus Iynnl

42 Laslurus boreal Is

43 Lasiurus intermedius

44 Nyticelus humeralis

45 Antrozous koopmanl

46 Tadarlda braslllensis

47 Tadarlda macrotis

48 Mormopterus minutus

49 Eumops aurlpendulus

50 Eumops slaucinus

51 Eumops perot 15

52 Molossus molossus

53 Tadarida lat l caudata

- 54 Mormoops megaphylla

- 55 Tonatla bldens

- 56 Phyllonycteris major

- 57 Desmodus rotundus

- Not extant in the Antilles.

- Extinct taxon. 
Phytophagous Species. -....... I ISLANDS

F denotes occurrence only as a foss 11 .
Remaining species.

\begin{tabular}{|c|c|c|c|c|c|}
\hline P25 & 00000 & 00000 & 00000 & 00000 & 00010 \\
\hline P26 & 11111 & 11010 & 10011 & 11111 & 11110 \\
\hline 27 & 110 & 000 & 00000 & 00000 & 00000 \\
\hline 28 & 110 & 00000 & 00000 & 00000 & 00000 \\
\hline 29 & 00 & 00000 & 00000 & 00000 & 00000 \\
\hline & 00 & 00000 & 00000 & 0111 & 00010 \\
\hline & & 00 & 00000 & 00111 & 00010 \\
\hline & & 00 & 000 & 00 & 00010 \\
\hline & & 00000 & 00000 & 00000 & 00000 \\
\hline & & & 00 & & \\
\hline & & 00 & 00 & 000 & 000 \\
\hline & & 00000 & 00000 & 00010 & 00000 \\
\hline & 00000 & 00000 & 00000 & 00001 & 00100 \\
\hline 38 & 00000 & 00000 & 00000 & 00000 & 00010 \\
\hline P39 & 01110 & 00000 & 00000 & 00000 & 00000 \\
\hline 40 & 000 & 00000 & 00000 & 00100 & 00000 \\
\hline $5 P 41$ & 100 & 00000 & 00000 & 000 & 200 \\
\hline SP 42 & 111 & 00000 & 00000 & 000 & 200 \\
\hline 43 & 01 & 00 & 00 & 00 & \\
\hline 44 & 01 & 00 & 00 & 00 & \\
\hline 45 & 01 & 000 & 00000 & 000 & \\
\hline 46 & & 000 & 10111 & 11 & \\
\hline 47 & & 00 & & & \\
\hline $\mathbf{S}$ & 01 & 000 & 00000 & 000 & 00 \\
\hline & 100 & 00000 & 00000 & 00000 & 00 \\
\hline & 110 & 00000 & 00000 & 00000 & 0000 \\
\hline & 010 & 00000 & 00000 & 00000 & 0000 \\
\hline & 111 & 11011 & 10111 & 11111 & 1111 \\
\hline & & 000 & & & \\
\hline & OF & 00000 & 00000 & 00000 & 0000 \\
\hline & & 000 & 00000 & & 0000 \\
\hline & & & 00000 & 00000 & 0000 \\
\hline & & & & & \\
\hline
\end{tabular}




\section{BIBLIOGRAPHY}

BAKER, R.J., and H.H. GenOWAYS, 1978. - Zoogeography of Antillean bats. In : Zoogeography of the Caribbean. (Gill, F.B., ed.) Philadelphia Acad. Nat. Sciences Spec. Publ. $13: 1-128$.

Baker R.J., H.H. Genoways and J.C. Patton, 1978. - Bats of Guadeloupe. Occas. Papers, Museum, Texas Tech. Univ., 50 : 1-16.

ConNOR, E.F., and E.D. MCCOY, 1979. - The statistics and biology of the species-area relationship. Amer. Nat., $113: 791-833$.

ConNor, E.F., and D. SimberlofF, 1978. - Species number and compositional similarity of the Galapagos flora and avifauna. Ecol. Mono., 48 : 219-248.

GILPIN, M.E., and J.M. DIAMOND, 1982. - Factors contributing to non-randomness in species' co-occurrence on islands. Oecologia, 52 : 75-84.

GILPIN, M.E., and J.M. Diamond, 1984. - Are species co-occurrences on islands nonrandom, and are null hypotheses useful in community ecology ? In : Ecological Communities; conceptual issues and the evidence. (D.R. Strong, D. Simberloff, L.G. Abele and A.B. Thistle, eds.) Princeton University Press, Princeton.

JONES, J.K., 1978. - A new bat of the genus Artibeus from the Lesser Antillean island of St. Vincent. Occ. Papers Museum Texas Tech. Univ., 51 : 1-6.

KOOPMAN, K.F., 1958. - Land bridges and ecology in bat distribution on islands off the northern coast of South America. Evolution, $12: 429-439$.

LAZELl, J.D., and L. JARECKI, 1985. - Bats of Guana, British Virgin Islands. Amer. Mus. Nov., 2819 : 1-7.

MACARThUR, R.H., and E.O. Wilson, 1967. - The theory of Island Biogeography. Princeton University Press, Princeton. $203 \mathrm{pp}$.

MCFARLANE, D.A., 1987. - The structure and development of the Antillean bat communities. Unpublished $\mathrm{PhD}$ dissertation, University of Southern California, August 1987. $237 \mathrm{pp}$.

OtTenwalder, J.A., and H.H. Genoways, 1982. - Systematic review of the Antillean bats of the Natalus micropus complex (Chiroptera ; Natalidae). Annals Carnegie Museum, 51 : 17-38.

SimberlofF, D., 1978. - Using island biogeographic distributions to determine if colonization is stochastic. Amer. Nat., $119: 345-357$.

WRIGHT, S.J., and C.C. BIEHL, 1982. - Island biogeographic distributions ; testing for random and aggregated patterns of species occurrence. Amer. Nat., $119: 345-357$. 